\title{
Symbols, Serfdom, and Peasant Factions: A Response to Hermann Rebel
}

\author{
David M. Luebke
}

7 HE main fault that Hermann Rebel finds with the practitioners of "symbolic actionism" is a tendency to naturalize systems of power and 1 cultural domination and to treat subaltern groups as if they were unable to examine their position in them critically. This tendency in turn causes symbolic actionists to misrecognize self-interested maneuvers within existing systems of domination as counterhegemonic symbolic manipulations. ${ }^{1}$ The overall effect of symbolic-actionist analysis, therefore, is to "downplay the degradation and terror experienced by victims of exploitation and persecution." 2 Rebel's view of such relationships could hardly differ more. As he sees it, hegemonic forces were so disruptive that to speak of peasant societies as culturally autonomous and of peasants as historical "agents" is at best self-deceiving. Gravely underestimating the force and psychological disruptions of hegemony, symbolic actionists thus misjudge the ability of subaltern groups to interrogate power and exaggerate the freedom of action available to them. This criticism is not new and joins a long-running and important debate between historians inspired by localist anthropologists such as Clifford Geertz, and globalists who, guided by the work of André Gunder Frank, Immanuel Wallerstein, Eric R. Wolf, and others, interpret local cultures and power relations from the perspective of a transnational, capitalistic system of domination. ${ }^{3}$

When applied to factional divisions in peasant society - the subject of my 1997 monograph His Majesty's Rebels - Rebel's globalist framework leads him to emphasize the weight of socioeconomic and psychological constraints on peasants' political stances. Deprived by hegemony of an integrated, intending self, peasants were only capable, in his view, of endorsing a path of political and

1. Hermann Rebel, "Cultural Hegemony and Class Experience: A Critical Reading of Recent Ethnological-Historical Approaches," American Ethnologist 16 (1989): 117-36 and 350-65; "What Do the Peasants Want Now?," 342-44.

2. Rebel, "Cultural Hegemony and Class Experience," 131, 351.

3. Aletta Biersack, "Local Knowledge, Local History: Geertz and Beyond," in The New Cultural History, ed. Lynn Hunt (Berkeley, 1989), 72-96, here 82-83. 
economic development toward "aristocratic-corporate" and "tribute-extracting" modernity or rebelling against it ${ }^{4}$ In Rebel's presentation, historical rightthinking is quite literally a matter of life and death, for to interpret factionalism differently is to accept the inevitability of political violence - past, present, and future. By interpreting factions in terms of the peasants' own intentionalities and by connecting their social form to peasants' kinship ties, dependencies, rituals, and behaviors, Andreas Suter and I have unwittingly placed ourselves on the wrong side of an "ongoing conversation about world-system ethics that may... countenance arguments about the necessary targeting of regional populations for destabilizing 'shocks' that may... devolve into historically predictable and therefore ... 'containable' massacres of peasants."

Obviously, it was never my intention to condone violence against peasants or anyone else; nor do I celebrate "least-worst victories of the "realists" over "fundamentalists" in the conflicts I analyzed, whether for our "posthistoric aesthetic edification" or any other reason. ${ }^{6}$ Such charges are indicative of Rebel's apparent need to see all scholarship as ideologically driven: his critique unfolds on two planes, the one a battlefield of the imagination in which historical interpretations necessarily follow political stances in the here-andnow, positionings which Rebel figures he can discern without much difficulty; the other plane a more conventional scholarly exchange over evidence and interpretation. ${ }^{7}$ As for the first plane, it would be counterproductive to engage his critique as if it were intended to achieve anything other than some species of historical truth. Instead, I disagree with its reductionism on both conceptual and empirical grounds.

4. Rebel, "Cultural Hegemony," 122; "What Do the Peasants Want Now?" 351.

5. "What Do the Peasants Want Now?," 356 (emphasis added).

6. Ibid., 320, 322, 342, 345, 356.

7. Rebel's failure to distinguish between historical analysis and ethical prescription generates a host of needless misrepresentations. To identify only a few of these: in Rebel's retelling, my narrative of peasants' legal victories is presented as a recommendation to view so-called fundamentalists as "ineffectual and self-contradicting." But my book is in no sense a brief for "realism" in politics, past or present, and I pass no judgment on the ability or inability of "fundamentalists" to "govern." Rather, I consider Rebel's question ahistorical and irrelevant, especially in view of the significant fact that leading "fundamentalists" actually did govern. To be sure, my book does suggest that the election to public office of "disobedient" peasants in the context of what elites liked to call "rebellion" generated considerable administrative turmoil, but it is wholly inappropriate to extrapolate normative endorsements from a commentary on the obvious. Similarly, Rebel misrepresents my references to "naïve monarchism" - a misguided concept I never invoked approvingly — as a programmatic encouragement to belittle peasants. Why, one wonders, would anyone want to do that? And again: factional strife was the dominant fact of political life in Hauenstein after 1727 at the latest, but Rebel insinuates that to comment on this is somehow to consign salpeterisch peasants to a "scripted role as irrational fundamentalists given to self-serving factional infighting." It is nothing of the sort. Rebel thinks it argues against my interpretation that exogenous shocks "initiated the process of threshold-crossing escalations," but in fact I emphasize that St. Blasien initiated the disruptions and 
In form and structure, Rebel's critique is a narrative of "system revolutions" that ostensibly excluded the county of Hauenstein from "imperial processes" in Vienna and transformed Leibeigenschaft (serfdom or "personal bondage" as Rebel prefers to call it) from a privileged status into a legal mechanism that amplified the tribute-extracting power of lords. As Rebel sees it, these "system revolutions" brought home to Black Forest peasants the impact of global market relations on a "repolarizing dynastic-corporatist world system." In his final analysis, factions formed around responses to these pressures and these alone: as he tells it, the salpeterisch faction consisted of peasants who favored a "centrally-adjudicated 'state-subject' status," as opposed to "realists" in the müllerisch faction who accepted provincialization and engineered the appropriation of Leibherrschaft rights for themselves "in return for the more limited economic and political opportunities of familial and communal involution" bargain sealed at the expense of their neighbors, wives, and children.

This account is stimulating and converges at several points with my own interpretation. But as an explanation for peasant factionalism, it neither comports with the historical evolution of Leibeigenschaft in Hauenstein, nor is it consistent with the social patterns and behaviors of factions during the "Salpeter Wars." As the first section of my response will show, the development of Leibeigenschaft in Hauenstein bore at best a passing resemblance to the process upon which Rebel bases his interpretation of salpeterisch political symbolism. Most fundamentally, his counternarrative misrepresents the relationship between leibeigen subjects and communal organization as conflictual, which in turn diverts attention from the constitutive role of communally-orchestrated peasant action in both the melioration and symbolic transformation of Leibeigenschaft throughout the period between 1350 and 1738. It also leads him both to assert as fact an "appropriation" of lordship rights that never actually occurred in the manner he imagines (see appendix 3). Finally, it leads him to misrepresent as a naked power-grab the signal achievement of peasant action during the "Salpeter Wars": the abolition of Leibeigenschaft and all its appurtenances. These errors of fact and interpretation lessen the explanatory power of Rebel's counternarrative and divert attention from what the peasants' contests over Leibeigenschaft were really about: the institutional integrity of Hauenstein as

that the role of Hauenstein's political elites was largely reactive. Having read only Rebel's critique, the weary reader might think that my book means to draw a sharp line between "peasant wars" and Everyday Life, but in fact one of my principle goals in His Majesty's Rebels was to undermine what I consider a fake and misleading distinction. Finally, Rebel misconstrues my case for an anthropological reformulation of Winfried Schulze's juridification thesis as a "conservative and ironic" endorsement of social control through litigation and appellate processes. And so on; $\mathrm{cf}$. "What Do the Peasants Want Now?," 319, 322, 339, 344, 345-46.

8. Ibid., 332 .

9. Ibid., 336 . 
a semi-autonomous corporate polity, the ability of its property-holders to dispose of their tenancies at will, and the threat posed to both by efforts to territorialize the instruments of rule.

A second section shows that in order to sustain his tidy congruence between factional ties and "world-system" choices, Rebel must distort or exclude from consideration evidence I presented on the cultural origins and social composition of factions, their goals and the tactics they crafted to achieve them, as well as the symbols and ideologies each faction deployed to legitimate its actions. The crucial points to bear in mind are that factional differences in Hauenstein emerged within an increasingly oligarchic but still relatively open peasant elite; that these differences were originally tactical in nature and reflected increasingly divergent solutions to a set of objectives that nevertheless enjoyed broad consensus; that these common goals expressed the socioeconomic interests of a property-holding, housefather-oligarchy; and finally that factional divisions only became unbridgeable as a consequence of military repression. I make no bones about the fact that one set of solutions conformed more closely to the behavioral expectations of state and seigneurial authorities, and it is disingenuous for Rebel to suggest that I do otherwise. Because Rebel ignores these findings he gets cause and effect exactly wrong: his tendency to extrapolate backward in time from a configuration of power that emerged a generation after the "Salpeter Wars" causes him to miss the fact that before and during the years of rebellion, neither faction was striving toward an authoritarian "system revolution." In short, there is a reason why I did not portray peasant factions simply as the product of choices for and against the tribute-extracting absolutist state. It is because this hypothesis is irreconcilable with the evidence I found.

There is a deeper issue at stake here. To boil factional politics down to such all-or-nothing choices involves propounding a conception of lord-subject relations that both obscures the complexity of rural power relations and drastically underestimates the range of tactical and strategic options that were available to early modern peasants. It must be stressed that Rebel's analysis is not some vulgar reduction of political action to class situation, but his tendency to present power relations in binary terms is related to a privileging of capitalistic market forces as the sole determinant of factionalization and, presumably, of peasant politics in general. Thus the ultimate arbiter of peasant action remains the hegemonic early modern state, thinking globally and coopting locally, the ineluctable guard at every peasant's point of entry into the global system of economic relations. This is, implicitly, to deploy a definition of counterhegemonic activity so strict as to exclude virtually all forms of nonviolent engagement with institutions of early modern rule - from petitioning to litigation to the withholding of homage, and so on.

It is also to accept at face value an authoritarian, eighteenth-century political dramaturgy in which peasants were cast as either obedient or rebellious, 
depending on the measure of ritual deference they displayed toward juridical or seigneurial authorities. But such a conceptualization skews the realities of rural politics in eighteenth-century Hauenstein. As they proved time and again, the county's political elite experienced no shortage of institutional wherewithal to manipulate a complex set of power relations, nor did they hesitate to pick and choose among a broad array of resistance practices, some of them "rebellious," others not. Such tactics were typically deployed within a broader politics of triangulation - a potent stratagem that persistently thwarted the efforts of lords to impose structural change unilaterally against the concerted opposition of peasants organized communally (see appendices 1 and 2). And Hauenstein was by no means unusual in these matters: as a host of recent studies have shown, the local executors of state and seigneurial power were embedded socially and politically to such an extent that their ability to function depended utterly on complex bargains struck with chancelleries in one direction and with subject populations in the other. ${ }^{10} \mathrm{~A}$ generation of research into early modern peasant revolts has shown that every resistance movement took shape as a learning process, in which specific tactics were taken up, discarded, or modified as experience taught and circumstances required. ${ }^{11}$ Rebel's insistence on measuring peasant action solely against the yardstick of hegemony leads him to draw a spuriously sharp contrast between opposition to power and tactical accommodations with its demands.

Again, none of this should be taken to diminish the socioeconomic causes of rebellion in Hauenstein or anywhere else. ${ }^{12}$ In my view, our differences have more to do with how one analyzes assessments of opportunity and risk in the past and their articulation in a range of tactical responses to ever-changing external pressures. At issue is the place of peasant action within a multipolar and multilayered "field of force." In Alf Lüdtke's words, this figure of Herrschaft "resists simple bipolarities":

10. For only the geographically most proximate comparisons, see Michaela Hohkamp, Herrschaft in der Herrschaft: Die vorderösterreichische Obervogtei Triberg von 1737 bis 1780 (Göttingen, 1998); idem, "Vom Wirtshaus zum Amtshaus," WerkstattGeschichte 16 (1997): 8-18; Ulinka Rublack, "Frühneuzeitliche Staatlichkeit und lokale Herrschaftspraxis in Württemberg," Zeitschrift für historische Forschung (hereafter ZHF) 24 (1997): 347-76; Achim Landwehr, Policey im Alltag: Die Implementation früneuzeitlicher Policeyordnungen in Leonberg (Frankfurt am Main, 2000). On implementation as a problem of cultural history, see Landwehr, "Normendurchsetzung' in der Frühen Neuzeit?: Kritik eines Begriffes," Zeitschrift für Geschischtswissenschaft 48, no. 2 (2000): 146-62.

11. In this connection see above all Werner Trossbach, Soziale Bewegung und politische Effahrung: Bäuerlicher Protest in hessischen Territorien, 1648-1806 (Weingatten, 1987), esp. 205-73; and the essays contained in Peter Blickle, et al., Aufnuhr und Empörung?: Studien zum bäuerlichen Widerstand im Alten Reich (Munich, 1980).

12. Luebke, His Majesty's Rebels, 121-41. 
To be sure, the relationship between rulers and the ruled is confrontational rulers constitute themselves through their powers of definition and disposition over the ruled. Still, rulers may find themselves in situations of dependency. And subjects are more than the passive addressees of their rulers' initiatives. Most importantly, inequalities and contradictions also reveal themselves among rulers as well as among the ruled. ${ }^{13}$

For me, the appeal of Lüdtke's figure is that it presents Herrschaft as an interaction in which communication is more than simply a matter of stimulus and response but a many-sided interaction, a circulation of influences among many, albeit mightily unequal parties. Of course, rulers possessed superior powers of definition - it would be ludicrous to suggest otherwise - and used this power to structure the range of potential options available to subjects. But it would be equally misleading to omit from consideration the dependence of effective rule on a certain "minimum of voluntary compliance, that is, an interest . . in obedience."

By the same token, we have to account for the effects of learning processes on conceptualizations of interest. How peasants sized up opportunity and risk in a multipolar field of force had everything to do with the experiences they brought to bear on a given situation, and in view of this we should not be surprised to discover that 200 years after the Peasants' War, Hauensteiners were still weighing the costs and benefits of armed rebellion as a means to achieve common goals. ${ }^{15}$ Nor should we be surprised to find certain faction leaders publicly advocating litigation over more demonstrative forms of resistance, even as others were insisting on the bankruptcy of such maneuvers. ${ }^{16}$ That factions formed in Hauenstein around the horns of a tactical dilemma may well have been a local idiosyncrasy, but the larger point remains that peasant politics were not simply reducible to some logic of state power or of global economic development. In sum: approaching power relations as a "field of force" liberates historical analysis from the constraints of state-centered polarities such as "rebellion" and "obedience" and allows one to conceptualize peasant action in terms more consonant with the experiences and expectations that informed it and the complex array of influences in which it unfolded.

\section{Serfdom and "System Revolution"}

Since "symbolic actionism" is the starting point of Rebel's critique, it is well to contrast our interpretations of salpeterisch political rituals. Rebel claims to

13. Alf Lüdtke, "Herrschaft als soziale Praxis," in Herrschaft als soziale Praxis: Historische und sozialanthropologische Studien, ed. idem (Göttingen, 1991), 9-63.

14. Max Weber, Economy and Society, ed. Guenther Roth and Claus Wittich, 2 vols. (Berkeley, 1978), 1:212 (emphasis added). For a development of this theme see Achim Landwehr's "Praxeology" of early modern Herrsthaft in Policey im Alltag, 313-29.

15. Luebke, His Majesty's Rebels, 58, 149-51, 154, 161, 173-74.

16. Ibid., 153-54, 182-84. 
explain better than my reading does the meaning of several ritually elaborate pilgrimages - most of them to the Marian shrine at Einsiedeln and several involving processions of crowned, white-clad, and candle-bearing Jungfrauenwhich the salpeterisch faction launched to inaugurate diplomatic missions to the imperial court in Vienna or other sites where they hoped to obtain justice. I speculated that these pilgrimages were crafted to convey a diverse set of messages to several audiences simultaneously: to Emperor Charles, they communicated pious loyalty and deflected the charge of rebellion; to fellow peasants, they identified the salpeterisch cause with corporate privileges and the imperial authority that guaranteed them, condemning by implication the müllerisch faction as treasonous against both community and emperor; to cofactionalists, finally, the power of these pilgrimages derived from the symbolic association of salpeterisch diplomatic goals with tradition, law, community. Moreover, I argued that through their overt use of nuptial ritual forms, the salpeterisch faction used imagery of sexual purity and pollution to identify Leibeigenschaft as the principle symbol of Hauenstein's collective ills and the müllerisch faction as the party responsible for its introduction. Similarly, I argued that summoning imperial authority was not "naïve" at all but profoundly autonomist, because it articulated a set of assumptions about how monarchs should behave that justified resistance to judicial-administrative bureaucracies and, potentially, the rejection of imperial authority itself. All of these messages derived force and meaning from the deeply factionalized political environment in which they were conceived and deployed, a context in which the aim of scoring a victory against the opposite camp weighed as heavily as any other. Tied as they were to diplomatic missions having the explicit goal of deposing a group of factional rivals, these rituals and their meanings were inextricably bound up with ongoing factional struggles between the salpeterisch and müllerisch coalitions and their competing claims to legitimate power through elective office. Ultimately, I concluded, these pilgrimages cannot be understood apart from the everyday to-and-fro of the factional politicking in which they were embedded. As their organizers' behavior made clear, the pilgrimages were about Hauenstein itself as a polity, control of its institutions, and the preservation of its corporate freedoms against attacks from the outside. Anyone interested in a full exposition of this argument can find it in my article "Naïve Monarchism' and Marian Veneration."17

Without explaining why or how, Rebel declares this explanation to be incommensurable with the material costs of salpeterisch pilgrimage and diplomacy. ${ }^{18}$ Instead, he argues, the pilgrimages were not about factional strife or the defense of corporate privileges per se but spoke instead to the loss of leibeigen reciprocities in a series of provincializing "system revolutions" and its effects on 
household economies and inheritance strategies. Borrowing heavily from the interpretations of Hannah Rabe, he argues that Leibeigenschaft originated as a mutually beneficial, strictly personal and privileged relationship between lords and dependents that was sharply distinct from mere Eigenschaft, a term that denoted the conventional, medieval fusion of rule over land with rule over the people who farmed it. ${ }^{19}$ According to this argument, late medieval Leibeigenschaft presented lords with a fictive kin-group of dues-paying "agents" inside villages who might act as a local political counterweight to locally powerful communal oligarchies. Bondsmen were willing to become leibeigen 1) because bondage contracts might exempt them from "communal supervisions, restrictions, taxations, and obligations," 2) because this status improved their bargaining position vis-à-vis landlords, and 3) because it would allow them to enter "a more complex set of "world system' relations." ${ }^{20}$ Rebel never fully explains how this might have worked, but the suggestion is consistent with Rabe's cheery characterization of late medieval Leibeigenschaft as a privileged personal status, unrelated to land tenure, that enabled its bearers to produce under license from the Leibherr-protector, free from communal regulation. Finally 4) the status empowered women in particular by making them attractive to non-leibeigen males who wanted access to the big advantages of Leibeigenschaft, both for themselves and their heirs.

All this changed, presumably, when provincialization transformed the institutional reciprocities of Leibeigenschaft into legal devices for augmenting the power of landlords. As a result, Leibeigenschaft no longer undermined the power of landlords but enhanced it; leibeigen women lost whatever inheritance advantages their status once conferred. As before, a pivotal issue was the distribution of power within villages. The difference was that now a conflict between those who did and did not accept provincialization displaced the older tensions. The circle of oppressors widened to embrace "realist" peasant-magistrates and separated them from the subaltern masses - as if masses had no say in their selection.

How well or poorly does this interpretation explain the structure and objectives of salpeterisch pilgrimages? Rebel does not dispute my contention that salpeterisch pilgrimages aimed at subverting an external power (St. Blasien) and its perceived agents (the müllerisch faction); nor does he challenge my insistence that they were meant to restore "lost" reciprocities between monarch and subject; nor does he dispute my argument that the fundamental issue was to

19. Hannah Rabe, Das Problem Leibeigenschaft: Eine Untersuchung über die Anfange einer Ideologisierung und des verfassungsrechtlichen Wandels von Freiheit und Eigentum im Deutschen Bauernkrieg (Wiesbaden, 1977), esp. 65-68, 81-104; and the reassertion of her thesis in her recent essay, "Wer waren die Leibeigenen und Königsleute Südwestdeutschlands?", Zeitschrift für Agrargeschichte und Agrarsoziologie (hereafter $Z A A$ ) 45, no. 1 (1997): 1-14.

20. "What Do the Peasants Want Now?," 336. 
maximize the ability of peasant-housefathers to dispose of property at will. For Rebel, though, salpeterisch pilgrimages were not creative appropriations of available ritual models or their attendant meanings to make a political point for tangible political gain but an expressive "textual-performative destabilization" of hegemonic power. In this reading, the symbolic association of a factional agenda with the monarch's well-being offered no special advantage, in part because Rebel denies the political instrumentality of ritual generally. Instead, the Jungfrauen drafted to participate in salpeterisch pilgrimages are a metonymic "celibacy figure" that expressed the supposed inability of peasants to manage family economies under restrictions on the partition of inheritances. Consequently, they symbolize only themselves - unmarried young people without provision, a condition that "realist" peasant oligarchs were complicit in creating. This would make good sense, 1) if families actually experienced such difficulties as a specific result of Leibeigenschaft; 2 ) if St. Blasien was actually able to enforce the ban against subdivision; and 3) if this were the only source of conflict between Hauenstein and the abbey. Even if these things were true and there is abundant empirical reason to doubt $\mathrm{it}^{21}$ - one would still want to know why salpeterisch dramaturges opted for a counterhegemonic performative destabilization if their aim was to restore a "centrally-adjudicated 'state-subject' status." Which "hegemon" does Rebel think they had in mind? He does not specify, for to do so would scramble his assignment of actions to world-system choices. Was "textual-performative destabilization" an end in itself, then? Because it assumes a sharp distinction between oppressors and the oppressed, crucial questions of agency and context go begging: who organized the ritual, and to what end? I will return to these questions by way of exposing three substantive flaws in the argument.

21. An analysis of Leibbücher from the Nöggenschwihl - a village located in the northeastern corner of Hauenstein - permits us to specify the basic marriage patterns of abbatial serfs (GLA 65: $11632,1 \mathrm{r}-57 \mathrm{r}$, comp. 1727-1730). The dominant characteristic was status-group endogamy: in the vast majority of the 189 marriages recorded during the period between ca. 1600 to 1730 , both the bride (169 cases) and groom (175 cases) were abbatial serfs, though this figure may be skewed by the source's genealogical purpose. The data on marriage rates is equivocal. These marriages produced a total of 600 offspring, an overall fertility rate of 3.17 offspring per marriage; of the 305 male offspring, 105 (34.4 percent) married, whereas only 72 (24.4 percent) of the female offspring did. These low rates, however, do not reflect the effects of infant mortality or unauthorized emigration. That unauthorized emigration was quite common is indicated by the unusually large percentage of marriages in which both bride and groom remained in the village (69.9 percent). In sum, we cannot say with confidence that serfs experienced any greater difficulty marrying off their children than non-serfs did. This should come as no surprise, since the vast majority of potential partners living within the geographical extent of Nöggenschwihl's marriage market was leibeigen. On balance, it is safe to conclude that finding a marriage partner was difficult, especially for women, but also that women experienced little specific disadvantage owing to leibeigen status. As for the subdivision of peasant holdings, finally, we know that the abbey was chronically unable to enforce bans against the partition of legally impartible Fronhofe; for an example see "Bericht wie der St. Blas: Lehen-FrohnHoff zu Birndorff seit vor Hundert Jahren hero vertheilet und von welchen Lehen-Leutehn solcher theilbar bisshero besessen worden" [1763], GLA 229:9112, no. 2. 
For one thing, it stands on historiographical feet of clay. ${ }^{22}$ As Claudia Ulbrich contends, southwest German Leibeigenschaft never was a strictly personal dependency unconnected to land tenure but originated with efforts by lords to minimize losses of power and income resulting from the gradual collapse of manorial economies and the demographic crises of the fourteenth century. ${ }^{23}$ To be sure, the local variants of late medieval Leibeigenschaft were idiosyncratic in the extreme. ${ }^{24}$ Still, Hannah Rabe's notion that fourteenth- and fifteenth-century bondsmen and women typically enjoyed greater freedom of movement, or that their status held out inheritance advantages specifically for women, contradicts what we know about the legal forms and original functions in Hauenstein. ${ }^{25}$ With respect to village power dynamics, the most salient difficulty with Rabe's hypothesis is simply that most people became leibeigen not by any choice but through matrilineal status inheritance, so that by 1400 or so, "communalists" were as likely to experience its benefits and impediments as anybody else. Not surprisingly, there is little evidence of conflict between the abbey's leibeigen dependents against "communalists" after the mid-fourteenth century. ${ }^{26}$ Indeed, Hauenstein's eight annually-elected magistrates (Octovirs) were representing abbatial Leibeigene in dealings with St. Blasien by 1371 at the latest. ${ }^{27}$ The upshot is twofold: 1) if ever there was a specific division of interest between Leibeigene and "communalists," it vanished more than three centuries before the "Salpeter Wars"; and 2) because abbatial Leibeigenschaft was never a strictly personal, privileged, or particularly beneficial status, one can hardly argue that eighteenth-century salpeterisch pilgrimages were about its loss. Rebel's critique

22. As Werner Trossbach explains, Rabe's hypothesis depends on a rationalist fallacy that the use of Leibeigenschaft as a polemical concept somehow undermines the historicity of leibeigen impediments on inheritance or freedom of movement; see Werner Trossbach, "Südwestdeutsche Leibeigenschaft' in der frühen Neuzeit - eine Bagatelle?" Geschichte und Gesellschaft (hereafter GuG) 7, no. 1 (1981): 69-90, here 85 .

23. The following relies on Claudia Ulbrich, Leibherrschaft am Oberrhein im Spätmittelalter (Göttingen, 1978), 253-308; and Trossbach, "Südwestdeutsche Leibeigenschaft." As Christian Keite] stresses, Leibeigenschaft also developed from its inception in close interaction with territoriallydefined forms of lordship; see his, Herrschaft über Land und Leute: Leibherrschaft und Territorialisienung in Würtemberg 1246-1593 (Leinfelden, 2000).

24. See Walter Müller, Entwicklung und Spätformen der Leibeigenschaft am Beispiel der Heiratsbeschränkungen: Die Ehegenosssame im alemannisch-schweizerischen Raum (Sigmaringen, 1974).

25. Rebel adopts these mistaken interpretations uncritically; "What Do the Peasants Want Now?," 334-36.

26. In Hauenstein, conflicts do appear to have emerged between the holders of manses (Fronhöfe) and communally-organized peasantries, but by the mid-fourteenth century Black Forest villagers had succeessfully absorbed abbatial lands into the communally-regulated cycle of planting and harvest; see Hugo Ott, Studien zur Geschichte des Klosters St. Blasien im hohen und späten Mittelalter (Stuttgart, 1963), 16-24. In any event, these conflicts had little specifically to do with the personal status - bonded or nonbonded - of the participants.

27. Josef Bader, "Urkundenregeste über das ehemalige sankt-blasische Waldamt," Zeitschrift für die Geschichte des Oberrheins (hereafter ZGO) 6 (1855): 226-50, 358-82, 466-87, here 364. 
carries more weight "if we follow Rabe's argument." 28 But few have, and for the good reason that her interpretation downplays grossly the constraints and exploitation that leibeigen status imposed.

Another flaw in Rebel's argument is that it presents as sequential phases what were more often concurrently evolving dimensions of the same late medieval dynamic: the territorialization of rule. ${ }^{29}$ From the standpoint of Leibherren, Rebel's concept of "provincialization" aptly characterizes many of the administrative techniques by which lords strove to reduce legal distinctions among various categories of subjection within territorially circumscribed jurisdictions to a uniform leibeigen dependency that entailed marriage impediments, restrictions on freedom of movement, annual recognition fees, and inheritance taxes. ${ }^{30}$ These innovations were not motivated by some conscious program of statebuilding, but by the need to preserve seigneurial incomes against the effects of peasant flight (Landflucht), especially to cities and towns, and against competition from other lords. ${ }^{31} \mathrm{~W}$ ürttemberg was paradigmatic for successful territorialization through the exploitation of fiscal losses: since the fourteenth century, its counts exploited the distress of poorer nobles by purchasing their leibeigen dependents, and from 1400 on, they began swapping serfs with neighboring lords in order to create a legally more uniform system of subjection within the emerging territorial state. In the late 1300 s, Leibeigene in Württemberg were forbidden to resettle outside their district $(A m t)$ of residence, and the internal process of territorialization was largely complete by the late sixteenth century. ${ }^{32}$ At an extreme, this territorialization united juridical, seigneurial, territorial, and personal forms of lordship in a single pair of hands. ${ }^{33}$

But the internal consolidation of rule was only half of a larger story. Beyond the limits of emerging territorial units, personal leibeigen obligations and inheritance duties extended the power of Leibherren into the jurisdictions of other lords and increased landed wealth at the latters' expense. Such predation in turn

28. "What Do the Peasants Want Now?," 335 (emphasis added).

29. Ulbrich, Leibherrschaft am Oberrhein; Trossbach, "Südwestdeutsche Leibeigenschaft," 76-77.

30. Luebke, His Majesty's Rebels, 45-47; Hans-Martin Maurer, "Die Ausbildung der Territorialgewalt oberschwäbischer Klöster vom 14. bis zum 17. Jahrhundert," Blätter für deutsche Landesgeschichte 109 (1973): 151-244; and André Holenstein, "Äbte und Bauern: Vom Regiment der Klöster im Spätmittelalter," in Politische Kultur in Oberschwaben, ed. Peter Blickle (Tübingen, 1993), 243-68.

31. Peter Blickle, "Agrarkrise und Leibeigenschaft im spätmittelalterlichen deutschen Südwesten," in Agrarisches Nebengewerbe und Formen der Reagrarisierung im Spätmittelalter und 19.-20. Jahrhundert, ed. Hermann Kellenbenz (Stuttgart, 1975), 39-54. Leibeigenschaft also enabled lords to acquire peasant freeholds, especially in Upper Swabia and the Black Forest, where a good deal still remained for the picking; cf. Holenstein, "Äbte und Bauern."

32. Keitel, Herrschaft iber Land und Leute, 210-29.

33. For example, the Cistercian Convent at Wald, near Sigmaringen; cf. Maren Rehfus, Das Zisterzienserinnenkloster Wald: Grundherrschaft, Gerichtsherrschaft und Verwaltung (Sigmaringen, 1971), $342-44$. 
provoked reactions that impelled territorialization even further: by the midfourteenth century, for example, the Praemonstratensian abbey of Schussenried had forced most of its tenants into leibeigen status, the better to protect itself against alienations resulting from the inheritance claims of competing Leibherren within its zone of jurisdiction. ${ }^{34}$ The point here is that these phases were concurrent manifestations of a single process distinguished by their legalpolitical relation to spatially bounded jurisdictions..$^{35}$ Of course, it would be misleading to suggest that Leibeigenschaft offered no benefit. The relationship imposed on lords a specific obligation to protect and defend. ${ }^{36}$ In certain instances, personal dependents paid lower rents than non-dependents. ${ }^{37}$ Leibeigen status was commonly the de facto, even de jure precondition for getting a tenancy. ${ }^{38}$ And possession of a Fronhof conferred authority over its dependents. ${ }^{39}$ But every benefit came at a price, and in villages subject to the Benedictine monastery of Kempten, it was a fifteenth-century "toboggan ride" into bondage, in which freeholders "were forced by jail sentences, monetary fines, and confiscation of estates 'voluntarily' to accept the abbey's serfdom." 40

This points at a third flaw in Rebel's analysis: even if we set aside the costs of entering Leibeigenschaft, it is difficult to see how the status conferred any special inheritance benefit on women. On the contrary, most lords treated Leibeigenschaft as an entitlement to large inheritance portions, and a few managed to disinherit leibeigen tenants entirely, men and women alike. ${ }^{41}$ In the

34. In the meantime, however, leibeigen dependents who were subject to the jurisdiction of someone other than their bond-lord might derive certain immunities from their status - as did the dependents of a noble convent in Buchau. These relationships appear to support Rabe's thesis, but as Ulbrich explains, peasants offered themselves to convents such as Buchau as a means of escaping harsher forms of leibeigen subjection. Ulbrich, Leibherrschaft am Oberrhein, 255-56; and see Eugen Stemmler, "Die Kornelier des Damenstifts Buchau: Ein Beitrag zur Frage der oberschwäbischen Leibeigenschaft," Zeitschrift fur Würtembergische Landesgeschichte 36 (1977): 10-48. The convent transformed these jurisdictional reservations into conventional Leibeigenschaft during the first decades of the sixteenth century.

35. Of course, Leibeigenschaft was by no means the only tool of internal consolidation. The Benedictine abbey of Ottobeuren used Grundherrschaft to much the same effect; see Peter Blickle, "Leibeigenschaft als Instrument der Territorialpolitik im Allgäu: Grundlagen der Landeshoheit der Klöster Kempten und Ottobeuren," in Wege und Forschungen der Agrargeschichte, ed. Heinz Haushofer and Willi A. Boelcke (Frankfurt am Main, 1967), 50-66.

36. I include this benefit even though most historians are hard put to demonstrate a concrete example of this obligation at work; see Ulbrich, Leibherrschaft am Oberrhein, 300-2; and Manfred Tischler, Die Leibeigenschaft im Hochstift Würzburg vom 13. bis zum beginnenden 19. Jahrhundert (Würzburg, 1963), 87-88. See also Gadi Algazi, Herrengewalt und Gewalt der Herren im späten Mittelalter (Frankfurt am Main, 1996), 56-96.

37. Stemmler, "Die Kornelier," 28-30.

38. In Württemberg, to cite but one example, comital lands were assigned only to peasants who agreed to assume leibeigen status; see Keitel, Herrschaft über Land und Leute, 194-97. Similarly within jurisdictions subject to the Cistercian Sisters of Wald; Rehfus, Zisterzienserinnenkloster Wald, 347.

39. Ott, Studien zur Geschichte des Klosters St. Blasien, 16-24.

40. Peter Blickle, The Revolution of 1525: The German Peasants' War from a New Perspective, trans. Thomas A. Brady, Jr. and H.C. Erik Midelfort (Baltimore, 1985), 53.

41. Schussenried accomplished this by converting all holdings in lifetime tenures; Saarbruicker 
majority of cases, however, leibeigen status - far from benefiting women in particular - seriously threatened the ability of parents to provide dowries for their daughters. ${ }^{42}$ In his study of Weingarten abbey, for example, David Sabean showed that when parents were bonded to different lords and both claimed a portion, the total inheritance could be reduced to a mere sixth of its original size. ${ }^{43}$ As their late fifteenth-century demands and negotiations indicate, Hauensteiners were keenly aware that this threat endangered the life-chances of children born to mixed marriages between male abbatial serfs and women dependent on a lord other than St. Blasien. ${ }^{44}$

One might ask why anyone accepted leibeigen status if it was so disastrous. A plausible answer would be that many, perhaps most, did not. The spectacular events of 1524-1526 must not divert our attention from the fact that peasant action had begun to transform Leibeigenschaft long before the Peasants' War. Most notably, resistance and litigation brought about the elimination of leibeigen inheritance claims in exchange for the fixed dues and monetized services characteristic of the early modern centuries. ${ }^{45}$ So it was in Hauenstein, where in 1467 an alliance between Octovirs and the forest steward - the local representative of Habsburg authority - compelled St. Blasien to abandon its claim to an inheritance portion in return for contractually fixed death duties and the continuation of limited jurisdictional prerogatives and recognition fees. ${ }^{46}$ Thus

Arbeitsgruppe, "Die spätmittelalterliche Leibeigenschaft in Oberschwaben," $Z A A 22$ (1974): 9-33; Wolfgang von Hippel, "Klosterherrschaft und Klosterwirtschaft in Oberschwaben am Ende des Alten Reiches: Das Beispiel Schussenried," in Gemeinde, Reformation und Widerstand, ed. Heinrich R. Schmidt, André Holenstein, and Andreas Würgler (Tübingen, 1998), 457-74.

42. Walter Müller, Die Abgaben von Todes wegen in der Abtei St. Gallen: Ein Beitrag zur Rechtsgeschichte des sanktgallischen Klosterstaates (Cologne, 1961), 11-14; Roberto M. Fröhlich, Die Eigenleute des Johanniterhauses Bubikon: Eigenschaft und Leibherrschaft im Herrschaftsbereich der Johanniterkomturei Bubikon, 1192-1789 (Zurich, 1993), 223-36.

43. David W. Sabean, Landbesitz und Gesellschaft am Vorabend des Bauernkrieges (Stuttgart, 1972), 90-94. Sabean argues that Weingarten abbey used leibeigen inheritance claims to acquire the remaining freehold property in its vicinity.

44. Luebke, His Majesty's Rebels, 42-43,111-12. There is a further reason why abbatial Leibeigenschaft conferred no inheritance benefit specific to women. Rebel's interpretation presumes that leibeigen status was transmitted through maternal inheritance. But St. Blasien treated leibeigen status as heritable through both parents. Thus the "benefits" of Leibeigenschafi could be had by marriage to any leibeigen subject, male or female.

45. Ulbrich, Leibherrschaft am Oberrhein, 49-76; idem, "Freiheit und Eigenschaft in spätmittelalterlichen ländlichen Rechtsquellen des Oberrheingebietes," in Deutsche ländliche Rechtsquellen: Probleme und Wege der Weistumsforschung, ed. Peter Blickle (Stuttgart, 1977), 185-97. Peter Blickle goes so far as to argue that pressure from subjects was primarily responsible for reducing Leibeigenschaft to an economically and politically unimportant dependency in the seventeenth and eighteenth centuries; see his "Von der Leibeigenschaft in die Freiheit," in Grund- und Freiheitsrechte im Wandel der Gesellschaft und Geschichte: Beiträge zur Geschichte der Grund- und Freiheitsrechte vom Ausgang des Mittelalters bis zur Revolution von 1848, ed. Günther Birtsch (Göttingen, 1981), 25-40, here 31 .

46. Dingrodel des Waldamts, 19 May 1467, excerpted in Josef Bader, "Urkundenregeste über die ehemaligen sankt-blasischen Niedergerichte," ZGO 7 (1856): 228-56, 328-50, here 235-39. 
leibeigen status was finally, formally unhinged from any relation to land tenure or juridical subjection. The advantage to family inheritance planning was obvious: in place of an economically debilitating inheritance share, families could marry their offspring as they pleased and could expect to pay a relatively predictable death duty. ${ }^{47}$ The crucial thing to note here is a movement toward greater freedom of disposition over tenancies facilitated by peasant magistrates who were able to manipulate a complex and multipolar political environment to the advantage of leibeigen housefather-proprietors. This was, arguably, a "leastworst" compromise that fell far short of the communalist dream of a world without lords. But unless one dismisses a priori all such settlements as nothing more than selling out, who is to say whether they were ethically corrupt or even fundamentally irreconcilable with the ideal of "turning Swiss"?

The 1467 deal is typical of late medieval territorial settlements and foreshadows three broad characteristics of early modern Leibeigenschaft in southwestern Germany. First and foremost, it draws attention to the enormous range of possibility for peasant action and its impact on the legal and symbolic evolution of that relationship throughout the early modern centuries. Rebel tends to explain the evolution of Leibeigenschaft as the outcome of one-sided shocks, administered to helpless dependents through the connivance of self-interested peasant oligarchs. But this misconstrues the substantive transformations of Leibeigenschaft and oversimplifies the means by which they occurred. As Werner Trossbach observes, "only as a result of conflicts between peasants and seigneurs did it acquire that ensemble of characteristics which jurists and constitutional historians later interpreted as the "signs' of Leibeigenschaft." ${ }^{+8}$ Secondly, the latemedieval prominence of third-party mediators anticipated the multipolarity of early modern social conflicts generally. Against persistent opposition, fifteenthand sixteenth-century Leibherren were rarely able to prevail on the strength of their own resources, with the result that a great many conflicts were resolved ad hoc through third-party mediation. But such mediators were often sympathetic to peasants' interests, especially if settlements could be made to favor their own territorial designs. ${ }^{+9}$ During the period after 1525 , peasants were more likely to

Though St. Blasien did not formally cede leibeigen marriage impediments and restrictions on freedom of movement, it is clear that enforcement of these rights had ceased even before the 1467 deal.

47. Most often Besthaupt or Bestvieh (in its myriad local manifestations). On death-duties the definitive case study remains Müller, Abgaben von Todes wegen. In Hauenstein, St. Blasien continued to claim a leibeigen inheritance portion against the estates of males and females who remained unmarried to the age of 50 . This so-called Hagestolzenrecht was finally abolished in 1728; see Luebke, His Majesty's Rebels, 70.

48. Trossbach, "Südwestdeutsche Leibeigenschaft," 75 (emphasis added).

49. In 1406, for example, Zürich acquired the role of mediator in exchange for bestowing citizenship rights on Hermann Gesler, lien administrator of Swiss Landvogtei Grüningen, a status the city later used to establish territorial sovereignty over the district. See Thomas Weibel, Erbrecht, Gerichtswesen und Leibeigenschaft in der Landvogtei Grüningen (Zurich, 1987), 21; Fröhlich, Eigenleute des Johanniterhauses Bubikon, 116-17. 
prosecute their interests through formal litigation in addition to supplication and more demonstrative forms of pressure, such as rent or homage boycotts a transformative process that Winfried Schulze characterized as "juridification" of social conflict. ${ }^{50}$ Thirdly, codification tended to ossify the legal underpinnings of agrarian relations, even as it drew them to the forefront of contestation between lords and subjects. After the 1467 deal, little changed in the formal structure of abbatial Leibeigenschaft until its abolition in 1738. This too was typical and led an earlier generation of historians to believe that early modern Leibeigenschaft was no more than an auxiliary form of taxation. Recent research, however, has emphasized the "subsidiary functions" of early modern Leibeigenschaft, in which lords deployed leibeigen privileges to reinforce other forms of domination. ${ }^{51}$ As I describe in His Majesty's Rebels, this played out locally in St. Blasien's assault on the ability of tenants to alienate and bequeath landed properties through limits on the minimum size of holdings and the obligation to register land transfers. ${ }^{52}$ Although I suggested reasons to suspect that this campaign was unsuccessful, I also argued that from the peasants' point of view, it did not necessarily matter, inasmuch as the threat of a damaging "innovation" could motivate as powerfully as any actual burden. We should not be surprised, therefore, to find Hauensteiners arguing that their accustomed freedom of disposition over property argued against the attribution of leibeigen status. ${ }^{53}$ In the early eighteenth century, opposition to St. Blasien's assault enjoyed a consensus that transcended factional differences.

These post- 1525 realities, in turn, indicate some of the reasons why salpeterisch rituals were primarily about the territorial and institutional integrity of Hauenstein, a symbolic connection in which Leibeigenschaft stood for a panoply of threats to peasant self-government. The formal structure of abbatial Leibeigenschaft had ossified at a moment when St. Blasien's effort to carve out a zone of territorial rule remained incomplete. As I see it, this had three effects. First, the disjuncture perpetuated conflicts over territorialization and the relationship between Leibeigenschaft and other forms of subjection. The terms of codification in 1467 - in particular the heritability of leibeigen status through both parents, not just mothers - allowed Leibeigenschaft to spread by marriage to embrace ever larger numbers of Hauensteiners, such that by the 1720 s, perhaps as many as 90 percent of the abbey's juridical subjects were leibeigen; in Hauenstein as a whole, the figure was closer to 60 percent at the time of the

50. Winfried Schulze recently revisited the impact of rebellion on lawmaking in his "Klettgau 1603: Von der Bauernrevolte zur Landes- und Policeyordnung," in Gemeinde, Reformation und Widerstand, 415-31.

51. Trossbach, "Südwestdeutsche Leibeigenschaft."

52. Luebke, His Majesty's Rebels, 62-63.

53. "Rationes rusticorum warumb sye nit leibeigen sein wollen," 25 February 1673, GLA $99: 458$, no. 2. 
"Salpeter Wars." ${ }^{54}$ Within the lower courts, demography and law were creating a legally homogenous subject population. Beginning in the seventeenth century, moreover, a succession of abbots tried to blur distinctions between leibeigen dependents and juridical subjects by requiring them all to perform homage to St. Blasien as their Leibherr. ${ }^{55}$ But the abbey's ongoing efforts to sever its lower courts from Hauenstein continued to founder on the opposition of ad hoc alliances between peasant magistrates, the Habsburg state, and its local representatives (see appendix 1). Thus ossification and peasant resistance combined to keep territorialization at the center of contestation and to focus it substantively on the texts of leibeigen homage oaths.

A second consequence of incomplete territorialization involved the perpetuation of late medieval leibeigen burdens well into the seventeenth and eighteenth centuries. For lords, the continuation of late medieval contests over territorialization within an ossified legal context placed a symbolic premium on collecting of leibeigen dues and services, however trivial, as a means of strengthening their hand against competitors. In places where a uniformly leibeigen subject population was combined with locally uncontested juridical rule, the need to collect servile dues was typically less urgent. Thus servile dues declined where all residents were leibeigen and subject to the same judicial authority. ${ }^{56}$ Not so in Hauenstein, where despite the fact that formal characteristics of Leibeigenschaft had long since ossified and nearly all juridical subjects were leibeigen too, battles over the weight of servile dues and the modalities of collecting them continued right down to the eve of the "Salpeter Wars." Indeed, as I pointed out in His Majesty's Rebels, one of the precipitants of that conflict was a unilateral effort by St. Blasien to increase servile dues over the years after 1715. By the same token, leibeigen subjects strove to diminish the material burdens of Leibeigenschaft, though without questioning the fundamental legitimacy of these payments as such. ${ }^{57}$ Since all of these conflicts were

54. Luebke, His Majesty's Rebels, 43. These estimates are based on a comparison between "Ohngefährlicher Auffsatz der fallbaren Leüthen in der Graffschaff Hawenstein," 28 February 1738, GLA 113:116, 26r--v; and "Graffschaff Hawensteinische Seelenbeschreibung," 20 November 1754, GLA 113:198. The former is an estimate compiled for the purposes of apportioning the manumission fee among St. Blasien's Leibeigene in Hauenstein; the second is chronologically the nearest estimate of Hauenstein's population that can claim any precision. Given the generally upward trend of population movements during the early eighteenth century, it is likely the estimate is artificially low.

55. "Formula juramenti seu homagy dero Niederichtlichen Underthonen," GLA 113:225, 238r. Similarly, tenants on abbatial lands located outside the lower court districts were required to deliver an oath identical to that of serfs; see "Formula juramenti deren so nicht gerichtliche Untertanen nacher St. Blasien seyndt," GLA 113:225, 373r.

56. For examples see Keitel, Herrschaft über Land und Leute; Theodor Ludwig, Der badische Bauer im achtzehnten Jahrhundert (Strasbourg, 1896); Rehfus, Zisterzienserinnenkloster Wald, 349-53.

57. These devices included retirement provisions - transferring movable and immovable property to heirs before death - even though the practices had been outlawed under an agreement between Hauenstein and the abbey concluded in 1671. For a case of Leibfall-evasion by means of retirement provision, see Hochamtsprotokolle, 27 January 1712, GLA 61:10648, 26v. 
carried out between St. Blasien and Hauenstein as a corporate entity, every one of them pertained indirectly to the peasantry's ongoing institutional ability to defend itself.

Recent work by Renate Blickle suggests a third effect that involved the symbolic transformation of Leibeigenschaft into a polemical figure (Kampfbegriff) for social and political injustice. ${ }^{58}$ From the mid-seventeenth century on, the interaction of custom with territorial legislation and Roman Law produced a geographically widespread tendency among the ordinary people of seventeenth- and eighteenth-century Germany to speak of Leibeigenschaft and slavery synonymously. This equation reflected their awareness of a jurists' tendency to measure contemporary Leibeigenschaft against the classical standard of Roman slave law, but it also attested to the experience of peasant-litigants and their ability to deploy these meanings counterhegemonically. ${ }^{59}$ The phenomenon was not, in other words, a case of acculturation but the production of new meanings and polemical devices through processes of creative appropriation. The Hauensteiners' references to all forms of abbatial subjection as böhmische Leibeigenschaft or Sklaverei likewise reflected the effects of such cultural communication and mirrored the abbey's own efforts to blur distinctions among various classes of subjects as a means to enhance its controlling authority over each. As a metonym for social and political injustice, Leibeigenschaft might be used to describe anything. For peasants acting in a context of belated territorialization, especially, it became an anti-image of corporate privileges and liberties as the last defense of local autonomy and freedom of disposition over property against a grasping lord. To argue that salpeterisch pilgrimages were about Leibeigenschaft as a generalizing figure for social and political injustices is merely to contextualize a geographically widespread cultural trend in a local dispute and to analyze peasant action in terms consonant with the concepts and linguistic tropes that peasants themselves used to describe the condition. It is not to impose anachronistic "political-historical rhetorics surrounding the figure" of serfdom. ${ }^{60}$

58. Renate Blickle, "Leibeigenschaft: Versuch über Zeitgenossenschaft in Wissenschaft und Wirklichkeit, durchgeführt am Beispiel Altbayerns," in Gutsherrschaft als soziales Modell:Vergleichende Betrachtungen zur Funktionsweise frühneuzeitlicher Agrargesellschaften, ed. Jan Peters (Munich, 1995), 53-79; and her "Appetitus Libertatis: A Social Historical Approach to the Development of the Earliest Human Rights: The Example of Bavaria," in Human Rights and Cultural Diversity: Europe, Arabic-Islamic World, Africa, China, ed. Wolfgang Schmale (Goldbach, 1993), 143-62.

59. Trossbach, "Südwestdeutsche Leibeigenschaft," 86; Renate Blickle, "Hausnotdurft: Ein Fundamentalrecht in der altständischen Ordnung Bayerns," in Grund- und Freiheitsrechte von der ständischen zur spätbürgerlichen Gesellschaft; Kurt Andermann, "Leibeigenschaft im pfälzischen Oberrheingebiet," ZHF 18 (1990): 281-303; Silke Göttsch, Alle für einen Mann: Leibeigene und Widerständigkeit in Schleswig-Holstein im 18. Jahrhundert (Neumünster, 1991), 300-9.

60. "What Do the Peasants Want Now?," 334. 


\section{Structures, Tactics, and Factions}

Only if one bears these relationships in mind can one get a clear picture of what factions were about. Rebel's critique presupposes that it is easy for historians to distinguish between those who accommodated the demands of rulers and those who refused. But as I show in His Majesty's Rebels, the differences separating salpeterisch from müllerisch peasants became irreconcilable only under the escalating effects of violent military repression in 1727 and after. This state of affairs left open a broad ground for agreement and even cooperation across factional lines, especially in the earlier stages of Hauenstein's upheavals. There was, for example, no fundamental dispute over the desirability of eliminating Leibeigenschaft, both as a status category and as a set of legal impediments and material burdens. Nor, as I have already pointed out, was there any dispute over the desirability of maximizing the ability of tenants to alienate and bequeath holdings without seigneurial or juridical constraint. By the same token, there was no fundamental disagreement between factions over the desirability of preserving Hauenstein's "ancient rights and freedoms," particularly the electoral customs that structured its internal power relations. Indeed, one of the most consistent demands of the müllerisch faction - Rebel's "agents for sovereign corporations and dynasties" - was for the restoration of elections that had been suspended at various points during the 1720 s, 1730s, and 1740s. Even then, a de facto power monopoly in the hands of state-appointed peasant magistrates and their lineages was imposed over the loud protests of müllerisch "realists" who appreciated more keenly than absolutist "reformers" the necessity to institutionalize acquiescence in the administration of justice and taxation through formal electoral approbation. Perhaps Rebel's designation of "realists" as the vanguard of an aristocratic-corporatist future aptly characterizes the late eighteenth-century generation of village Honoratioren in Hauenstein who inherited the authoritarian system of domination imposed after the "Salpeter Wars." But to ascribe it to their fathers and grandfathers in the $1720 \mathrm{~s}$ and $1730 \mathrm{~s}$ is to indulge the anachronisms that are often embedded in cui bono argumentation.

The most plausible explanation for these patterns had everything to do with the social and institutional bases of peasant action and the multipolar context in which it took shape. Rebel's construction of options leaves little room for the possibility that a single, increasingly oligarchic political and social elite, when confronted with a multiplicity of tactical options, might disagree over the best approach to take and then factionalize under the impact of military repression, despite broad agreement on general goals. Yet the evidence I found suggests just such a scenario. If, for example, müllerisch peasants were "agents for sovereign corporations and dynasties" bent on dragging their fellows through ethically corrupt compromises into "aristocratic-corporate" and "tribute-extracting" modernity, then one might at least expect to discover some positive correspondence 
between office holding and identification with the müllerisch faction. But the striking thing about leaders on both sides of the factional divide is their similarity of background and experience. An analysis of the leading individuals on the "rebellious" salpeterisch side revealed a large number of veteran office holders. Among fifty-one individuals identified by Habsburg authorities in 1728 as the "main ringleaders" of rebellion, ten had served as Octovir, three collected quitrents for St. Blasien, two were cellarers for the noble convent of St. Fridolin in the town of Säckingen, eight held impartible abbatial Fronhöfe, and at least two were village headmen. Salpeterisch leaders, in short, represented a cross-section of Hauenstein's political and social elite, and in this respect they were poorly distinguishable from leaders of the "peaceable" müllerisch faction. Common to both groups were a disproportionately large number of individuals whose productive activtity placed them at central nodes of rural communication millers, especially, but also taverners, blacksmiths, and bottom-rank seigneurial functionaries. ${ }^{61}$ Similarly, an investigation of factional alignments in one of Hauenstein's eight cantons revealed that the social similarity of faction leaders was reproduced among the rank and file; it also suggested a strong tendency toward familial cohesion within factions. ${ }^{62}$ Factional divisions, in other words, were not organized horizontally according to class or subject status, but vertically, around kin and dependence. With only Rebel's critique to go by, one would never know that many so-called fundamentalist leaders were the wellto-do executors of state, seigneurial, and communal authority or that the whole popularion was divided more or less evenly.

By the same token, Hauenstein's internal power structure argues against an exclusively state-centered world-system analysis. The sixteenth-century Upper Austrian peasants whom Rebel studied may well have lacked institutional resources for effective resistance against predatory lords like St. Blasien, but Hauensteiners did not. For most everyday purposes, Hauenstein's annuallyelected Octovirs - whether "fundamentalist" or "realist" - were themselves the territorial government of Hauenstein: they levied public taxes, collected rents on royal lands in the county, sat on several appellate tribunals within the county, and represented Hauenstein in the Outer Austrian provincial Estates. ${ }^{63}$

61. Luebke, His Majesty's Rebels, 90-146.

62. David M. Luebke, "Terms of Loyalty: Factional Politics in a Single German Village (Nöggenschwihl, 1725-1745)," in Infinite Boundaries: Order, Reorder, and Disorder in Early Modern German Culture, ed. Max Reinhart and Thomas Robisheaux (Kirksville, 1998), 77-105.

63. They also exercised lower jurisdiction over the villages of Hänner and Willaringen and enjoyed formal command of a territorial militia, the Landfahnen, although for military purposes this institution was largely moribund by the eighteenth century. The Landfahnen did, however, reemerge during the "Salpeter Wars" as a designation that both factions used for their respective militias. On the Landfahnen see Karl F. Werner, "Der Hauensteiner Landfahnen: Entstehung, Entwicklung, und Bedeutung der hauensteiner Wehrorganisation bis zum Begin der Unruhen in der Grafschaft im Jahre 1726," ZGO 95 (1943): 301-97; and Luebke, His Majesty's Rebels 78, 81-84. 
Moreover, Hauenstein's relatively inclusive electoral customs exerted such a decisive influence on cultural constructions of authority and its legitimation that factionalism cannot properly be understood apart from it. ${ }^{64}$ All this enabled the Octovirs to bargain from a position of considerable strength. But in an environment increasingly hostile to autonomous decision-making by subaltern groups, a prohibition against self-succession in office also predisposed them to factionalization. In light of these realities, it requires no "theology of free will" to see that Hauenstein's political elites could draw on greater institutional resources and enjoyed a wider range of strategic and tactical options than Rebel's fate-laden counternarrative would allow. It is also easy to see why factions would take enormous risks to oust Octovirs in the enemy camp: ultimately, election was the only legitimate path to local power. Reading only Rebel's critique, one would never know that factions might have to pay for "selling out" with expulsion from power at the annual election of Octovirs on St. George's Day.

These circumstances, in turn, reflect larger structures in the social and political landscapes of early modern Central Europe. As we all know from the exhaustive studies of Peter Blickle, Outer Austria, Switzerland, and the Tyrol all sat within a "communal-cooperative" zone of Central Europe, where communal institutions were especially well developed and where local decision-making was integrated in various ways with fiscal administration at the provincial or territorial level. This entire region was encircled by lands - among them Upper Austria - where rural populations played little or no role in territorial administration. ${ }^{65}$ It is fair to criticize Blickle for a legal-institutional and cultural structuralism that can obscure the effects of social stratification on village life and the construction of sociopolitical norms. ${ }^{66}$ But his fundamental insight remains crucial: not all early modern peasantries were equally vulnerable to political domination and cultural hegemony, and one must not overlook the effect of institutional supports on their ability to resist effectively and to leave their stamp on structures of power. ${ }^{67}$ To reduce these complex relations to simple, helpless choices for or against the hegemonic state is to miss the consti-

64. Luebke, His Majesty's Rebels, 30-35. Let it be duly noted that these "elections" bore only a remote resemblance to modern democratic practices.

65. Peter Blickle, Kommunalismus: Skizzen einer gesellschaflichen Organisationsform, vol. 1, Oberdeutschland (Munich, 2000); idem, Landschaften im Alten Reich: Die staatliche Funktion des gemeinen Mannes in Oberdeutschland (Munich, 1973).

66. See Robert von Friedeburg, “'Kommunalismus' und 'Republikanismus' in der Frühneuzeit? Überlegungen zur politischen Mobilisierung sozial differenzierter ländlicher Gemeinden unter agrar- und sozialhistorischem Blickwinkel," ZHF 21 (1994): 65-91; and Peter Blickle's response in "Begriffsverfremdung: Über den Umgang mit dem wissenschaftlichen Ordnungsbegriff Kommunalismus," ZHF 22 (1995): 246-53.

67. See the European contextualizations by Steinar Imsen and Günter Vogler, "Communal Autonomy and Peasant Resistance in Northern and Central Europe" and by Peter Blickle, Steven 
tutive influence that peasant action exerted on legislation and the processes of its implementation. ${ }^{68}$

In view of these findings I concluded that to characterize the salpeterisch faction as "rebellious" and the müllerisch as "peaceable" would be to accept the tendentious classification schemes of Habsburg officialdom and other cultural outsiders, who ascribed mentalities to individuals and factions according to the deference they displayed. Rebel reinscribes this state-centered diagnosis as a distinction between "fundamentalists" and "realists" and then attributes it to me. But this, too, is misleading. In His Majesty's Rebels, I described distinct but originally compatible modes of engaging with early modern state and peasant society, one more legitimist in inclination, the other more creative and confrontational, and showed how they acquired ideological rigidity under the pressure of state intervention. True, future salpeterisch partisans had long exhibited greater frustration with litigating by the book, as it were, and also possessed a keener appreciation of the potential threat that St. Blasien's various judicial and seigneurial innovations posed. But as both factions proved by their own actions, there was nothing irreconcilable about these differences until military intervention polarized tactical disagreements into ideological oppositions. Even after that point had been reached, müllerisch peasants behaved in ways that by any state-centered standard of conduct should have counted as "rebellious." 69 Perhaps most crucially, müllerisch peasants were fully conscious of the authorities' inability to think outside a behaviorist box and encouraged fears of salpeterisch unrest as a means to pry concessions from St. Blasien and the provincial governments seated in Freiburg im Breisgau and Innsbruck - most notably the abolition of Leibeigenschaft in 1737-1738 (see appendix 3). In the end, the responses they crafted proved more effective at diminishing the power of lords. But there was nothing inevitable about this.

Ultimately, Rebel's contrasts are not so much false as unhelpful: confronted with potentially overwhelming violent force, one can defy and one can

Ellis, and Eva Österberg, "The Commons and the State: Representation, Infuence and the Legislative Process," both in Resistance, Representation and Community, ed. Peter Blickle (Oxford, 1997), 5-43 and $115-53$ respectively.

68. For the influence of peasant action on legislation, see the studies contained in Peter Blickle, ed., Resistance, Representation and Community (Oxford, 1997); and idem, ed., Gemeinde und Staat im alten Europa (Munich, 1998), especially Andreas Würgler, "Desideria und Landesordnungen: Kommunaler und landständischer Einfluss auf die fürstliche Gesetzgebung in Hessen-Kassel, 1650-1800," 149-215; Renate Blickle, "Laufen gen Hof: Die Beschwerden der Untertanen und die Entstehung des Hofrats in Bayern: Ein Beitrag zu den Varianten rechtlicher Verfahren im späten Mittelalter und in der frïhen Neuzeit," 241-66; and André Holenstein, "Bittgesuche, Gesetze und Verwaltung: Zur Praxis 'guter Policey' in Gemeinde und Staat des Ancien Régime am Beispiel der Markgrafschaft Baden-Durlach,” 267-355.

69. Having said that, we must not forget that as factional rivalries hardened, the müllerisch faction effectively offered itself to Habsburg and abbatial authorities as a political surveillance network; see Luebke, His Majesty's Rebels, 72-73. 
accommodate, but rarely is a single course of action clearly one or the other. To pose the options in black-and-white terms, as Rebel does, is to dismiss virtually all forms of peasant action (symbolic or otherwise) as little more than accommodationism. It is also to indulge an ahistorical conceit that peasant politics were made up of all-or-nothing ethical propositions. It is to posit an exclusive alignment between "realist" modes of political engagement and the material interests of housefather oligarchy; it is also to erect a phony polarity between counterhegemonic demonstrations and political maneuvers "within the system." If the "Salpeter Wars" were unusual, after all, it was because these various modes of engaging state and society became grist for the mill of factional difference. In the majority of early modern cases, "rebellion" and more "peaceable" forms of peasant action were wholly compatible resistance practices. ${ }^{70}$ As for Hauenstein, it should be possible to analyze how factions interacted without somehow condoning the state violence that was deployed to wreck the institutions that both factions wanted to preserve.

\section{Appendices}

\section{1) The "Eternal Perpetuation" of 1705}

The triggering event in Rebel's narrative of "system revolutions" is the "eternal perpetuation" by imperial decree of St. Blasien's lien on the administration of the so-called Zwing und Bann - a district immediately surrounding the abbey itself that bordered on Hauenstein to the north. This "perpetuation" was the latest in a series of agreements between the abbey and the Habsburg state going back to 1596, when Emperor Rudolf II first ceded powers of higher jurisdiction over the Zwing und Bann for thirty-five years as security for an interest-free loan of 20,000 Gulden. ${ }^{71}$ Even before the term had expired, Austria renewed the cession in return for an additional loan, and so it went periodically until 1705. But the 1705 deal differed from earlier agreements in that it lacked an expiration date: this time, Austria ceded higher and lower jurisdiction over the Zwing und Bann in perpetuity in return for a cancellation of all debts to St. Blasien, both interest bearing and noninterest bearing. ${ }^{72}$

70. See Trossbach, Soziale Bewegung und politische Evfahming, 174-202; idem, Im Schatten der Aufklärnng: Bauern, Bürger, und Illuminaten in der Grafschaft Wied-Neuwied (Fulda, 1991), 130-40.

71. 1. Pfandshandlung, 6 August 1596, in Bader, "Urkundenregeste über die ehemaligen sanktblasischen Niedergerichte," $246-47$. The judicial powers in question embraced the right to try offenses up to and including the capital. For the second, third, and fourth Pfandshandlungen (5 November 1627, 21 September 1655, and 15 April 1705), see ibid., 248, 253, 328-30, respectively. I used the word "lease" to describe these deals in order to emphasize their essence, namely the temporary cession of ownership rights in return for a cash payment in the form of a noninterestbearing loan (that was never repaid).

72. Leopold's instruction cited the figure of 300,000 Gulden; "Resolutionsschreiben des Kaisers Leopold an die oberösterreichische geheime Stelle," 16 August 1704, in Bader, "Urkundenregeste 
As it pertains to the Zwing und Bann, Rebel describes the 1705 deal accurately as an attempt to privatize public authorities. But Rebel also thinks that this deal severed abbatial lower courts located inside the boundaries of Hauenstein from "imperial processes" in Freiburg, Innsbruck, and Vienna, and this is at best half true. To be sure, the perpetuation confirmed the route of judicial appeal from the lower courts to the abbatial chancellery, but this state of affairs had obtained in various forms since the late Middle Ages. ${ }^{73}$ Furthermore it is mistaken to suggest that the crown ceded "earnings" from Hauenstein to St. Blasien in 1705; on the contrary, Austria recovered certain court receipts that had been ceded to St. Blasien back in $1627 .{ }^{74}$ Finally, Austria never ceded higher jurisdiction over the abbatial lower courts inside Hauenstein. As I explain in His Majesty's Rebels, the significance of the 1705 deal lay not so much in abrupt changes but in the future threat that "perpetuation" posed to Hauenstein's institutional integrity. ${ }^{75}$

One cannot underestimate the effects of peasant action in its defense. The perpetuation of 1705 was coupled with imperial recognition and renewal prompted by the Octovirs' diplomatic efforts in Vienna - of Hauenstein's "freedoms, rights and privileges," including its privilegio de non alienando and with this ongoing inclusion in the imperial apparatus of judicial-administrative appeal. ${ }^{76}$ That this was no idle promise was revealed in 1719 , when the Habsburg forest steward intervened at the Octovirs' prompting to mediate a settlement with St. Blasien that aborted the abbey's attempt to raise monetized leibeigen dues and court fees unilaterally, and we should not be surprised to discover that several future müllerisch leaders were among the magistrates who negotiated this intervention. ${ }^{77}$ To be sure, St. Blasien continued to insist (as it had since the late Middle Ages) that its lower courts inside Hauenstein were private property - and the abbey seems to have interpreted the 1705 decree in

über die ehemaligen sankt-blasischen Niedergerichte," 328-29. Wernet estimates that the total indebtedness was closer to 400,000 Gulden; Karl F. Wernet, "St. Blasiens Versuche, sich der Grafschaft Hauenstein pfandweise zu bemächtigen," ZGO 107 (1859): 161-82, here 182.

73. The seventeenth-century route of appeal in St. Blasien's judicial system is described in "Verzeichnis der Gerichten, so man von St. Blasmischer Cantzley zu verwalten ... hat" [1638], GLA 99:79; a published version of this account may be found in Bader, "Urkundenregeste über die ehemaligen sankt-blasischen Niedergerichte," 248-53.

74. Austria also recovered the right to collect the "shrove chicken" from all households within the Zwing und Bann - a total annual payment of 194 chickens - which had been ceded to St. Blasien in 1655; the right to collect this recognition tax was restored to St. Blasien to 1715 in return for imperial confirmation of the 1705 "perpetuation" and yet another non-interest-bearing loan of 20,000 Gulden.

75. Luebke, His Majesty's Rebels, 59.

76. For an excerpt of this recognition decree, see Josef Bader, "Urkunden und Regeste aus dem Archive der ehemaligen Grafschaft Hauenstein," ZGO 10 (1859):353-84; 11 (1850): 465-90, here 11:487,

77. Luebke, His Majesty's Rebels, 64. 
this spirit, as Rebel does too ${ }^{78}$ And as I make plain, the monastery's aim was to remove these courts from the feudal nexus of divided ownership and reciprocal obligation. But claiming ownership and making the claim stick were two very different things, and St. Blasien could not prevail against an ad hoc alliance between Hauenstein's peasant magistrates and Outer Austrian provincial authorities, who were determined to keep the lower courts enmeshed in the web of divided and multilayered rule. In sum: Rebel's assessment of the "eternal perpetuation" exaggerates its practical impact.

\section{2) The Hofkanzleiordnung of 1720}

Another crucial episode in Rebel's narrative involves the Hofkanzleiordnung (HKO) of 26 March 1720 and the constraints it allegedly imposed on peasant action. Rebel has this decree excluding Hauensteiners specifically from "imperial processes" in Vienna, and sure enough, Article 3 of the HKO forbade direct appeals to the imperial chancellery and redirected them to appellate tribunals of the first and second instance. ${ }^{79}$ But Rebel's cause-and-effect notion of how implementation happened leads him to misconstrue the practical impact of the HKO. On the one hand, the imperial chancellery had been sending Hauensteiners home with instructions to litigate through regular channels long before 1720 and it would continue to issue such instructions long after 1720 as well. But the chancellery also continued to hear and act on direct appeals before and after the ostensible "system revolution" of 1720 , and for reasons that go to the heart of "absolutist" political culture. In the Habsburg lands as elsewhere, the gradual territorialization of royal authority went hand in glove with efforts to restrict direct personal appeals to the supreme justiciar. At the same time, however, monarchs and their ministers recognized that this process generated considerable legitimation pressure on royal authority and crafted a variety of devices to relieve it, which included permitting a certain number of direct appeals to proceed. $^{80}$ One need not accept Jürgen Schlumbohm's recent

78. "Urkundlicher Ausszug deren Rechten undt Freyheiten des uralten löbl. Stifts St. Blasien am Schwartzwaldt" [n.d.], GLA 65:11398. On the distribution of jurisdictional competences in St. Blasien's lower courts, see Ott, Studien zur Geschichte des Klosters St. Blasien, 69-77.

79. Rebel seems to think that the "exclusion" was selective; but nothing in the relevant clause suggests that it was: "Es solle unsere hofcanzlei keine sachen, die nicht ihrer besonderen aigenschaft nach oder sonst von rechts- und gewohnheitswegen unmittelbar für uns gehören, mit hindansetzung der ersteren oder anderen ordentlichen instanzien an sich ziehen, vielmehr aber diejenige, so mit vorbeigehung der ersteren und subordinirten instanzien sich zu unserem hof immediate wenden wollen, zuruck an ihre behörde verweisen..."; Instruktion Kaiser Karls VI. für die österreichische Hofkanzlei, 26 March 1720, $\$ 3$; reprinted in Thomas Fellner and Heinrich Kretschmayr, Die österreichische Zentralvenwaltung (Vienna, 1907; reprint Nendeln, 1970), pt. 1, vol. 3, Aktenstücke 1683-1749, 347-75, here 365-66.

80. See Renate Blickle, "Supplikationen und Demonstrationen: Mittel und Wege der Partizipation im bayerischen Territorialstaat," Kommunikation in der ländlichen Gesellschaft vom 
suggestion that the promulgation of "laws that were not enforced" was a structural characteristic of early modern governance to see that even a provision so seemingly unequivocal as $\mathrm{HKO}$ Article 3 left plenty of room for business as usual. ${ }^{81}$

\section{3) The Manumission of 1738}

The capstone of Rebel's provincialization narrative is the manumission treaty concluded on 15 January 1738 and ratified in June, which he presents as a transfer of Leibherrschaft rights to Hauenstein as a corporation under the administration of its peasant-magistrates, the Octovirs. But this is mistaken: with one minor exception, the 1738 treaty did not transfer abbatial Leibherrschaft to any lord or corporation, but got rid of it entirely. ${ }^{82}$ All the legal disabilities, marriage impediments, limits on freedom of movement, and dues or services that attached to serfdom were terminated in return for 58,000 Gulden, which was paid out in five annual installments. The treaty was never renegotiated, never annulled; as part of the settlement, St. Blasien agreed never to attempt to "implant" serfdom in the county again. Within the territorial limits of Hauenstein, there were no abbatial serfs after the manumission fee was paid off on 2 October 1742 and St. Blasien surrendered its Leibbücher - the genealogical record and legal proof of inherited serf status. ${ }^{83}$

Thus emancipation was the status quo ante to which Hauenstein returned after the second outbreak of violent confrontation in 1738-1739. It is true that the treaty transferred Leibherrschaft to Hauenstein as a corporate entity over a small number of formerly abbatial dependents resident in Indlekofen, a hamlet located within the jurisdictional limits of the town of Waldshut, and in three other villages located outside the boundaries of Hauenstein proper ${ }^{84}$ But this transfer did not apply to the formerly abbatial serfs resident in Hauenstein proper. This comprehensive abolition was far more radical than the pseudo-emancipation that Emperor Joseph II decreed in December 1782: in Hauenstein after 1738,

Mittelalter bis zur Moderne, ed. Werner Rösener (Göttingen, 2000), 263-318. André Holenstein shows how these transformations played out in the ritual of homage; Die Huldigung der Untertanen: Rechtskultur und Herrschaftsordnung (800-1800) (Stuttgart, 1991), 342-84, 493-95 and passim.

81. Jürgen Schlumbohm, "Gesetze, die nicht durchgesetzt werden - ein Strukturmerkmal des frühneuzeitlichen Staates?" GuG 23/4 (1997): 647-63.

82. Recess zwischen St. Blasien und Hauenstein wegen Befreiung von der Leibeigenschaft und der Fallbarkeit, 15 January 1738, GLA 11:3135.

83. For the receipt of final payment on the manumission fee, see GLA 11:3140; and Bader, "Urkundenregeste über die ehemaligen sankt-blasischen Niedergerichte," 350.

84. Luebke, His Majesty's Rebels, 74-75, 79. According to estimates compiled for the purposes of dissolving serfdom, there were 257 abbatial serfs resident in Indlekofen, as against 11,048 in the Hauenstein proper; "Specification wievill Männer Weiber undt Kindter so nacher St. Blasien fahlbar seindt, bey der Undersuchung dem 28 isten July 1739 so zue Dogern beschehen sich in denen 8 Einungen ... befundten," GLA 113:111, n.p. 
there were no more legal impediments to marriage, no more restrictions on emigration or change of residence, no more shrove chickens to pay, and most important, no more death duties to surrender. ${ }^{85}$ These may seem like hair-splitting distinctions, but they make all the difference. The transfer of Leibherrschaft in Hauenstein is a figment of Rebel's imagination.

UNIVERSITY OF OREGON

85 "Patent über die Aufhebung der Leibeigenschaft in Vorderösterreich," Vienna, 20 December 1782; in Wolfgang von Hippel, Die Bauernbefreiung im Königreich Württemberg, vol. 2, Quellen (Boppard, 1977), 35-36. The decree eliminated all marital contraints, restrictions on freedom of movement, and established a uniform schedule of Manumissionsgeld, but left all the dues and service appertaining to serf status in tact. 